\title{
Response of Sweet Potato to Mycorrhizae and Irrigation Treatments Under Drip Irrigation in Sandy Soils
}

\author{
Attia $^{1}$, M.M.: Rmadan ${ }^{2}$, Abdel Aty and M. El., Moursy ${ }^{1}$
}

\begin{abstract}
Two field experiments were conducted at Aly Mubarak experimental farm, El-Bustan region during 2006 nd 2007summr seasons to study the response of sweet potato to two mycorrhiza, vesicular-arbuscular mycorrhizal (VAM) fungi treatments $(w=$ inoculation with VAM and $w_{0}=$ non VAM) and four irrigation treatments (irrigation with amounts of water equals: $I_{1}=120 \%$, $I_{2}=100 \%, I_{3}=80 \%$ and $I_{4}=60 \%$ of crop evapotranspiration ETc ).

Results revealed that there were significant effects due to the interaction between the tested mycorrhizae and irrigation treatments on the production of sweet potato through the two growing seasons. The highest yields of sweet potato tuber were 10.742 and 10.425 ton/fed. in the two growing seasons, respectively, that obtained by inoculation with mycorrhizae and irrigation with amount of water equals to $80 \%$ of ETc. Also, the inoculation with mycorrhizae and irrigation with amount of water equals to $80 \%$ ETc $\left(I_{3}\right)$ gave the highest values of tuber sweet potato (number/plant, tuber weight, tuber length, tuber diameter and TSS. But, the inoculation with mycorrhizae and irrigation with amount of water equals to $120 \%$ ETc $\left(I_{1}\right)$ gave the highest values of leaf area, foliage weight and tuber phosphorus content of sweet potato.
\end{abstract}

The total amounts of applied irrigation water for the $80 \%$ ETc irrigation treatment of sweet potato were 65.0 and $67.3 \mathrm{~cm}$. in the two growing seasons, respectively. The highest water utilization efficiency (WUtE) values were 3.93 and $3.69 \mathrm{~kg}$ tuber sweet potato per $\mathrm{m3}$ irrigation water, in the first and second seasons, respectively, that obtained by inoculation with mycorrhizae and irrigation with amount of water equals to $80 \% \mathrm{ETc}$.

\section{INTRODUCTION}

Sweet potato (Ipomoea batatas L. lam) is an important crop in tropical, subtropical and warm temperature regions of the world. It was believed to e native of tropical America. Nowadays, it is one of the important vegetable crop in Egypt and other countries in the world due to its importance as a human food, as a raw material for industrial purposes, such as starch and alcohol production, and as an animal food.

Edible portions are the encaged storage roots which called tubers and are tuberous roots thickened secondary roots. It is considered as a cheep source of carbohydrates, and excellent source of B-carotene, vitamins (B1, B2 and C), protein (1.5-2.5\%) and other nutrients, such as (P, K, $\mathrm{Ca}$ and $\mathrm{Mg}$, which could make it a valuable food for nutritional problems in developing countries, where about $98 \%$ of world production occurs.

In Egypt, sweet potato is considered to be $\mathrm{n}$ important vegetable crop for local consumption. Egypt is ranked twenty-fifth among the production countries in the world. Egypt produces about 135000 tons yearly with an average yield of 10.44 tons/fed.

The importance of mycorrhizae inoculation for increasing plant resistance to water stress condition was suggested by several investigators (O'keefe and Sylvia (1992) and Vladimir and Bucher 2005).

On the other hand, water is the limiting factor for agricultural production in arid and semi-arid regions, where irrigation is required either intensively or extensively. Effect of water stress on yield potential had been reported by several researchers, Said et al (1984) declared that total yield of sweet potato roots, significantly increased with increasing soil moisture content up to the highest level. Nair and Nair (1995) declared that providing irrigation at cumulative pan evaporation during the tuber root initiation phase increased number of leaves per plant and leaf area of sweet potato plants. Abd El-Fattah et al (2001) found that the concentrations of photosynthetic pigments of taro plants were significantly decreased under water stress, which was imposed at different growth stages. Abd El-Fattah and Sorial (2001) found that 16\% and $15 \%$ reduction in corm yield of taro plants due to water stress imposed at vegetative growth and corm enlargement stages, respectively. El-Araby Salem (2002) found that the foliage fresh weight (kg/plant) and leaf area per plant $\left(\mathrm{m}^{2}\right)$ of sweet potato plants were significantly reduced due to water stress treatments, compared with unstressed plants. The drought treatment at vegetative growth stage, significantly increased the total tuberous roots yield of sweet potato, compared with the unstressed plants.

The objectives of this work were to study the effects of four irrigation treatments and inoculation with mycorrhizae on tuber sweet potato yield and yield components, water requirements and water utilization efficiency under drip irrigation system in sandy soils.

1Soil, Water and environment Res. Institute, ARC.

${ }^{2}$ Horticulture Res. Institute, ARC.

Received December18, 2008, Accepted December 25, 2008 


\section{MATERIALS AND METHODS}

Two field experiments were conducted at Aly Mubarak experimental farm at El-Bustan area, south Tahrir region during 2006 and 2007 summer growing seasons. The experimental site represents the newly reclaimed sandy soils where modern irrigation systems (drip and sprinkler) are introduced to the farmers of the area.

The drip irrigation system used in the experimental farm includes an irrigation pump connected to sand and screen filters and a fertilizer injector. A 63 out diameter PVC sub-main line, connected to it lateral poly ethylene lines of $16 \mathrm{~mm}$ out diameter. Each lateral is $30 \mathrm{~m}$ long and $0.8 \mathrm{~m}$ apart with standard $4 \mathrm{~L} / \mathrm{h}$ and emitters spaced at $0.3 \mathrm{~m}$ apart. The actual discharge rate was $3.6 \mathrm{~L} / \mathrm{h}$ due to pressure drop. The class A pan in the experimental farm was used to determine the amounts of applied irrigation water to the tested irrigation treatments.

Field capacity, wilting point, available soil moisture and bulk density values for the soil of the experimental site were determined and are listed in (Table 1).

The tested variables in this experiment comprised two mycorrhizae treatments and four irrigation treatments as follows:

$\mathrm{w}=$ inoculation with VAM

$\mathrm{w}_{0}=$ non $-\mathrm{VAM}$ inoculation

$\mathrm{I}_{1}=$ irrigation with amount of water equal to $120 \%$ of

ETc based on class A pan.

$\mathrm{I}_{2}=$ irrigation with amount of water equal to $100 \%$ of

ETc based on class A pan.

$\mathrm{I}_{3}=$ irrigation with amount of water equal to $80 \%$ of Etc based on class A pan.

$I_{4}=$ irrigation with amount of water equal to $60 \%$ of Etc based on class A pan.

Where ETc is the actual evapotranspiration.

A split plot experimental design with four replicates was used. The main plots were assigned to the irrigation treatments, while the sub plots were assigned to the mycorrhizae treatments. The experimental unit consists of six drip lines.

During land preparation, $30 \mathrm{~kg} \quad \mathrm{P}_{2} \mathrm{O}_{5} / \mathrm{fed}$. (as calcium super phosphate, $15 \% \mathrm{P}_{2} \mathrm{O}_{5}$ ) and $10 \mathrm{~m}^{3} /$ fed of chicken manure were added. During the growing season, $30 \mathrm{~kg} / \mathrm{fed} \mathrm{N}$ (as ammonium nitrate, $33.5 \% \mathrm{~N}$ ) and $96 \mathrm{~kg} \mathrm{~K}_{2} \mathrm{O}$ (as potassium sulfate, $50 \% \mathrm{~K}_{2} \mathrm{O}$ ) were injected through the irrigation water in eight doses.

Abese, sweet potato variety was sown on the $5^{\text {th }}$ and $10^{\text {th }}$ of May and was harvested on $10^{\text {th }}$ and $14^{\text {th }}$ of September in the first and second seasons, respectively.
The amounts of irrigation water were calculated according to the equation given by Vermeiren and Jopling, 1981 as follows:

$$
A I W=\frac{\text { ETo X Kc X kr X I }}{\mathrm{Ea}}+L R
$$

Where;

AIW $=$ depth of applied irrigation water $(\mathrm{mm})$,

ETo $=$ reference evapotranspiration $\left(\mathrm{mmd}^{-1}\right)$,

$\mathrm{Kc}=$ crop coefficient of sweet potato, FAO,56,

$\mathrm{Kr}=$ reduction factor, depends on ground cover, a value

of 1.0 was used (where the spacing is between drip

lines less than $1.8 \mathrm{~m}, \mathrm{FAO}, 56$,

I = irrigation intervals (days),

$\mathrm{Ea}=$ irrigation efficiency of the drip irrigation system, an

average value 0.8 was used as determined in the

beginning of each season after Ismail, (2002).

$\mathrm{LR}=$ Leaching requirements, $(10 \%$ of the calculated

irrigation water).

Reference evapotranspiration (ETo) values were calculated from class A pan measurements as follows;

$E T O=$ Epan $\mathrm{X} \mathrm{K}$ pan

(Dorenbos and Pruitt, 1984)

E pan is the measured pan evaporation values (mm/day) and $\mathrm{K}$ pan is the pan coefficient that equals 0.75 for the experimental site.

Irrigation time was determined before an event by measuring the actual emitter discharges according to the equation given by Ismail, (2002) as follows:

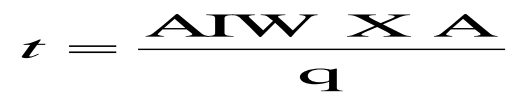

Where:

$\mathrm{t}=$ irrigation time $(\mathrm{h})$,

$\mathrm{A}=$ wetted area and

$\mathrm{q}=$ emitter discharge $(\mathrm{L} / \mathrm{h})$

AIW = applied irrigation water.

Water utilization efficiency (WUtE) values were calculated according to Jensen (1983) as follows:

tuber of sweet potato $(\mathrm{kg} / \mathrm{fed})$

$\mathrm{WUtE}=\overline{\text { irrigation water applied cubic meters / fed }}$

Phosphorous use efficiency $=$ tuber sweet potato yield $\mathrm{kg} / \mathrm{fed} . / \mathrm{P}_{2} \mathrm{O}_{5}$ added $\mathrm{kg} / \mathrm{fed}$.

The obtained data were statistically analyzed according to technique of analysis of variance (ANOVA) for the split plot design as described by Steel and Torrie (1960). Means were separated using the least significant differences (L.S.D.) method at 0.05 probability level. 
Table 1. Field capacity (FC), wilting point (Wp), available soil moisture (ASM) and bulk density (BD) values for the experimental site

\begin{tabular}{lllll}
\hline Soil depth cm. & FC $(\%)$ & Wp $(\%)$ & ASM $(\%)$ & BD $\left(\mathbf{g c m}^{-1}\right)$ \\
\hline $0-15$ & 11.2 & 5.3 & 5.9 & 1.46 \\
$15-30$ & 10.9 & 5.1 & 5.8 & 1.66 \\
$30-45$ & 9.5 & 4.6 & 4.9 & 1.71 \\
$45-60$ & 9.2 & 4.2 & 5.0 & 1.83 \\
\hline Average & 10.2 & 4.8 & 5.4 & 1.66 \\
\hline
\end{tabular}

Table 2. Chemical and particle size distribution of the soil at the experimental site

\begin{tabular}{|c|c|c|c|c|c|c|c|c|c|c|c|c|c|}
\hline \multirow[t]{2}{*}{$\begin{array}{l}\text { Soil } \\
\text { depth }\end{array}$} & \multirow[t]{2}{*}{$\begin{array}{l}\text { EC } \\
d S / m\end{array}$} & \multirow[t]{2}{*}{ pH } & \multicolumn{7}{|c|}{ Soluble cations and anions (meq/L.). } & \multicolumn{3}{|c|}{$\begin{array}{l}\text { Particlesize } \\
\text { distribution }\end{array}$} & \multirow[t]{2}{*}{$\begin{array}{l}\text { Texture } \\
\text { Class }\end{array}$} \\
\hline & & & $\mathrm{Ca}^{2+}$ & Mg2+ & $\mathrm{Na}^{+}$ & $\mathbf{K}^{+}$ & $\mathrm{HCO3}^{-1}$ & $\mathrm{Cl}^{-1}$ & $\mathrm{SO}^{2-}$ & $\begin{array}{l}\text { Sand } \\
\%\end{array}$ & $\begin{array}{l}\text { Silt } \\
\%\end{array}$ & $\begin{array}{l}\text { Clay } \\
\%\end{array}$ & \\
\hline $0-30$ & 0.38 & 9.2 & 1.25 & 0.60 & 1.60 & 0.20 & 1.18 & 1.8 & 0.75 & 90.9 & 3.6 & 5.5 & Sandy \\
\hline $30-60$ & 0.32 & 9.3 & 1.10 & 0.55 & 1.44 & 0.15 & 1.02 & 1.6 & 0.63 & 91.5 & 2.8 & 5.7 & sandy \\
\hline
\end{tabular}

RESULTS AND DISCUSSION

1.Tuber sweet potato yield and yield components:

-Tuber sweet potato yield:

Table 3 Showed that the mycorrhizae treatments are significantly influenced tuber sweet potato yield in the two growing seasons. The inoculation with VAM (w) gave the highest values of sweet potato (8.686 and 8.718 ton/fed) recording significant increases of 8.6 and $13.1 \%$ in the first and second seasons, as compared with non inoculated, respectively. Results also, indicated that tuber sweet potato yield was significantly affected by the irrigation treatments in the two growing seasons. Irrigation treatment $\left(\mathrm{I}_{3}\right)$ gave the highest values of tuber sweet potato yield (10.285 and 9.862 ton/fed) recording significant increases of 63.1, 10.4 and $37.7 \%$ in first season and 54.1, 7.9 and $32.3 \%$ in the second season as compared with $I_{1}, I_{2}$ and $I_{4}$ irrigation treatments, respectively. The interaction between the tested variables was significant. So, the maximum tuber sweet potato yields of 10.742 and 10.425 ton/fed was obtained by irrigation treatment $I_{3}$ and by inoculation with mycorrhizae (w) in the two respective seasons. It was clear from results that sweet potato plants are sensitive to excess of soil moisture. The obtained results are in agree with those reported by Said et al (1983), Abd El-Fattah and Soryal (2001) and El-Araby Salem (2002).

Table 3.Total tuber yield (ton/fed) of sweet potato as affected by irrigation and mycorrhizae treatments during summer growing seasons 2006 and 2007

\begin{tabular}{|c|c|c|}
\hline \multirow[t]{2}{*}{ Treatments } & \multicolumn{2}{|c|}{ Total tuber yield (ton/fed) } \\
\hline & Season 2006 & Season 2007 \\
\hline \multicolumn{3}{|l|}{ Irrigation: } \\
\hline $\mathrm{I}_{1}$ & 6.303 & 6.400 \\
\hline $\mathrm{I}_{2}$ & 9.315 & 9.137 \\
\hline $\mathrm{I}_{3}$ & 10.285 & 9.862 \\
\hline $\mathrm{I}_{4}$ & 7.470 & 7.450 \\
\hline LSD 0.05 & 0.299 & 0.270 \\
\hline \multicolumn{3}{|l|}{ Mycorrhizae: } \\
\hline W & 8.686 & 8.718 \\
\hline $\mathrm{W}_{0}$ & 8.000 & 7.706 \\
\hline LSD 0.05 & 0.148 & 0.341 \\
\hline \multicolumn{3}{|l|}{ Interactions: } \\
\hline $\mathrm{I}_{1} \mathrm{X} \mathrm{W}$ & 6.332 & 6.750 \\
\hline $\mathrm{I}_{1} \mathrm{X} \mathrm{\textrm {w } _ { 0 }}$ & 6.275 & 6.050 \\
\hline $\mathrm{I}_{2} \mathrm{Xw}$ & 9.890 & 9.925 \\
\hline $\mathrm{I}_{2} \mathrm{X} \mathrm{w_{0 }}$ & 8.740 & 8.350 \\
\hline $\mathrm{I}_{3} \mathrm{Xw}$ & 10.742 & 10.425 \\
\hline $\mathrm{I}_{3} \times \mathrm{w}_{\mathrm{o}}$ & 9.827 & 9.300 \\
\hline $\mathrm{I}_{4} \mathrm{X} \mathrm{w}$ & 7.805 & 7.775 \\
\hline $\mathrm{I}_{4} \mathrm{X} \mathrm{w}_{\mathrm{O}}$ & 7.157 & 7.125 \\
\hline LSD 0.05 & 0.422 & 0.382 \\
\hline
\end{tabular}


-Yield components:

Tables 4 and 5 showed that the VAM and irrigation treatments significantly influenced yield components of sweet potato in the two growing seasons. The inoculation with mycorrhizae and irrigation with $80 \%$ ETc $\left(\mathrm{I}_{3}\right)$ gave the highest values of tuber per plant, tuber weight, tuber length, tuber diameter and TSS of sweet potato. But, the inoculation with VAM and irrigation with $120 \%$ ETc $\left(I_{1}\right)$ gave the highest values of leaf area, foliage weight and tuber phosphate content of sweet potato. The obtained results agree with those reported by (O'keefe and Syivia (1992, Abd El-Fattah et al (2001), El-Araby Salem (2002) and Vladimir and Bucher (2005)).

Table 4. Tuber number/plant (TN)), tuber weight (TW), tuber length (TL) and tuber diameter (TD) of sweet potato as affected by irrigation and VAM treatments during the growing seasons 2006 and 2007

\begin{tabular}{llccccccc}
\multicolumn{1}{c}{ Treatments } & \multicolumn{3}{c}{ TN } & \multicolumn{2}{c}{ TW ( g) } & \multicolumn{2}{c}{ TL ( cm) } & \multicolumn{2}{c}{ TD ( cm) } \\
\cline { 2 - 9 } & $\mathbf{2 0 0 6}$ & $\mathbf{2 0 0 7}$ & $\mathbf{2 0 0 6}$ & $\mathbf{2 0 0 7}$ & $\mathbf{2 0 0 6}$ & $\mathbf{2 0 0 7}$ & $\mathbf{2 0 0 6}$ & $\mathbf{2 0 0 7}$ \\
\hline Irrigation & & & & & & & & \\
$\mathrm{I}_{1}$ & 3.38 & 3.25 & 142.7 & 141.6 & 13.96 & 15.66 & 6.21 & 6.66 \\
$\mathrm{I}_{2}$ & 3.88 & 4.00 & 153.8 & 154.1 & 17.68 & 17.75 & 8.46 & 8.47 \\
$\mathrm{I}_{3}$ & 4.50 & 4.25 & 152.2 & 153.6 & 18.30 & 18.22 & 9.02 & 10.26 \\
$\mathrm{I}_{4}$ & 2.50 & 2.25 & 143.8 & 146.0 & 15.46 & 15.38 & 6.52 & 9.42 \\
LSD 0.05 & 0.47 & 0.56 & 3.1 & 5.6 & 0.29 & 0.27 & 0.57 & 0.31 \\
Mycorrhizae & & & & & & & & \\
W & 3.94 & 3.94 & 148.7 & 152.1 & 16.90 & 17.33 & 7.88 & 9.41 \\
W $_{0}$ & 3.19 & 2.94 & 147.3 & 145.5 & 15.79 & 16.17 & 7.22 & 7.99 \\
LSD 0.05 & 0.32 & 0.32 & N.S. & 5.1 & 0.17 & 0.18 & 0.47 & 0.27 \\
Interactions & & & & & & & & \\
LSD 0.05 & N.S. & N.S. & N.S. & N.S. & N.S. & N.S. & N.S. & N.S. \\
\hline
\end{tabular}

Table 5. af area (LA), foliage fresh weight (FFW), TSS and tuber phosphate content (TPC) of sweet potato as affected by irrigation and VAM treatments during the growing seasons 2006 and 2007

\begin{tabular}{lcccccccc}
\hline Treatments & \multicolumn{2}{c}{$\begin{array}{c}\text { LA } \\
\left(\mathbf{~ m}^{2} / \mathbf{p l a n t}\right)\end{array}$} & \multicolumn{2}{c}{$\begin{array}{c}\text { FFW } \\
\text { (kg/plant) }\end{array}$} & \multicolumn{2}{c}{$\begin{array}{c}\text { TSS } \\
(\boldsymbol{\%})\end{array}$} & \multicolumn{2}{c}{$\begin{array}{c}\text { TPC } \\
\text { (\%) }\end{array}$} \\
\cline { 2 - 9 } & $\mathbf{2 0 0 6}$ & $\mathbf{2 0 0 7}$ & $\mathbf{2 0 0 6}$ & $\mathbf{2 0 0 7}$ & $\mathbf{2 0 0 6}$ & $\mathbf{2 0 0 7}$ & $\mathbf{2 0 0 6}$ & $\mathbf{2 0 0 7}$ \\
\hline Irrigation & & & & & & & & \\
$\mathrm{I}_{1}$ & 2.11 & 2.22 & 2.17 & 2.17 & 7.23 & 7.17 & 0.28 & 0.26 \\
$\mathrm{I}_{2}$ & 1.78 & 1.91 & 1.77 & 1.86 & 7.80 & 7.83 & 0.23 & 0.23 \\
$\mathrm{I}_{3}$ & 1.86 & 1.82 & 1.73 & 1.77 & 8.18 & 8.19 & 0.19 & 0.19 \\
$\mathrm{I}_{4}$ & 1.13 & 1.30 & 1.17 & 1.23 & 8.45 & 8.42 & 0.18 & 0.19 \\
LSD 0.05 & 0.10 & 0.08 & 0.14 & 0.10 & 0.14 & 0.20 & 0.10 & 0.09 \\
Mycorrhizae & & & & & & & & \\
W & 1.82 & 1.94 & 1.87 & 1.90 & 8.18 & 8.19 & 0.24 & 0.24 \\
W $_{0}$ & 1.62 & 1.68 & 1.55 & 1.61 & 7.65 & 7.62 & 0.20 & 0.20 \\
LSD 0.05 & 0.09 & 0.10 & 0.12 & 0.10 & 0.23 & 0.16 & 0.01 & 0.01 \\
Interactions & & & & & & & & \\
LSD 0.05 & N.S. & N.S. & N.S. & N.s. & N.s. & N.S. & N.S & N.S. \\
\hline
\end{tabular}

\section{Amount of irrigation applied water:}

The monthly and seasonally amounts of irrigation applied water to the sweet potato plants according to the irrigation treatments during the two growing seasons are listed in Table 6 . The highest monthly value of applied irrigation water occurred during July in both seasons for the all irrigation treatments. The total amount of applied irrigation water for the $120,100,80$ and $60 \%$ of ETc irrigation treatments were $97.8,81.3,65.0$ and $48.9 \mathrm{~cm}$ in the $1^{\text {st }}$ season and they were 100.7, 84.1, 67.3 and $50.4 \mathrm{~cm}$ in the $2^{\text {nd }}$ season, respectively. The obtained data agree with those investigators (Kashyap and ponda (2002) and Bao zhong et al (2003)). 
Table 6. onthly and seasonally amounts of applied irrigation water in $(\mathrm{cm})$ to sweet potato as affected by irrigation treatments during the summer growing seasons 2006 and 2007

\begin{tabular}{lcccccc}
\hline Treatments & \multicolumn{7}{c}{ Season 2006 } \\
\cline { 2 - 7 } & May & June & July & Aug. & Sep. & Total \\
\hline $\mathrm{I}_{1}$ & 10.1 & 21.2 & 36.1 & 28.2 & 2.2 & 97.8 \\
$\mathrm{I}_{2}$ & 8.3 & 17.6 & 30.1 & 23.5 & 1.8 & 81.3 \\
$\mathrm{I}^{3}$ & 6.6 & 14.4 & 24.1 & 18.8 & 1.4 & 65.0 \\
$\mathrm{I}_{4}$ & 5.0 & 10.6 & 18.1 & 14.1 & 1.1 & 48.9 \\
\hline Treatments & \multicolumn{7}{c}{ Season $\mathbf{2 0 0 7}$} \\
& May & June & July & Aug. & Sep. & Total \\
\hline $\mathrm{I}_{1}$ & 6.3 & 20.5 & 42.2 & 27.9 & 3.8 & 100.7 \\
$\mathrm{I}_{2}$ & 5.3 & 17.1 & 35.2 & 23.3 & 3.2 & 84.1 \\
$\mathrm{I}^{3}$ & 4.2 & 13.7 & 28.2 & 18.6 & 2.6 & 67.3 \\
$\mathrm{I}_{4}$ & 3.2 & 10.2 & 21.1 & 14.0 & 1.9 & 50.4 \\
\hline
\end{tabular}

2.Water utilization efficiency (WUtE):

Table 7 showed that the maximum WUtE values were obtained by inoculation with VAM when irrigated with amount of water equals $80 \%$ ETc in the two growing seasons. The obtained data of WUtE were 3.93 and $3.69 \mathrm{~kg}$ tuber sweet potato per cubic meter of

irrigation water in the first and second seasons, respectively.

Phosphorous use efficiency (PUE):

The effect of inoculation with VAM and yield of tuber sweet potato in the two growing seasons 2006 and 2007 is shown in fig. 1 . The highest of phosphorous use efficiency was obtained from the inoculation treatments.

PUE for tuber sweet potato as affected by mycorrhizae inoculation.

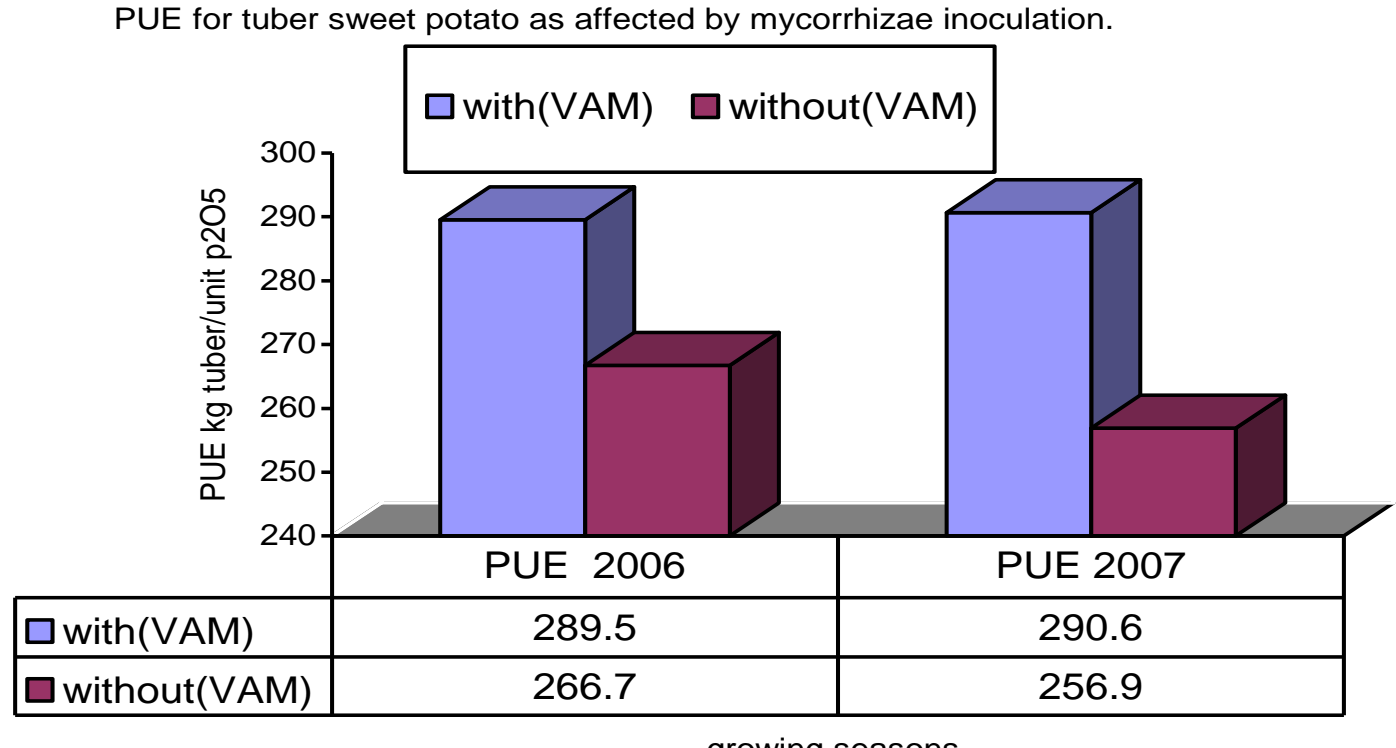

Figure 1. Phosphorous use efficiency for tuber sweet potato as affected by VAM treatments

Table 7. Water utilization efficiency (WUtE) for sweet potato as affected by irrigation treatments and VAM during 2006 and 2007 growing seasons

\begin{tabular}{lccc}
\hline Irrigation treatments & \multirow{2}{*}{ Mycorrhiza(VAM) } & \multicolumn{2}{c}{ WUtE $\left(\mathbf{k g}\right.$ tuber $\left.\mathbf{m}^{\mathbf{3}}\right)$} \\
\cline { 2 - 4 } & & Season 2006 & Season 2007 \\
\cline { 2 - 4 } $\mathrm{I}_{1}$ & With & 1.54 & 1.59 \\
\hline $\mathrm{I}_{2}$ & Without & 1.52 & 1.43 \\
& With & 2.89 & 2.81 \\
\hline $\mathrm{I} 3$ & Without & 2.55 & 2.36 \\
\cline { 2 - 4 } & With & 3.93 & 3.69 \\
\hline $\mathrm{I} 4$ & Without & 3.60 & 3.29 \\
\cline { 2 - 4 } & With & 3.80 & 3.67 \\
\hline
\end{tabular}




\section{CONCLUSIONS:}

It could be concluded that;

- Maximum tuber sweet potato yield was obtained by inoculation with mycorrhizae (VAM) and when irrigated every two days with amount of water equals $80 \%$ ETc under drip irrigation system.

- The inoculation with mycorrhizae gave the highest value tuber phosphorous content of sweet potato.

- Seasonal average of irrigation requirements for tuber sweet potato was $66.2 \mathrm{~cm}$ under drip irrigation system in sandy soils.

- The highest WUtE for tuber sweet potato was obtained from inoculation with mycorrhizae and when irrigated every two days with amount of water equals $80 \%$ ETc.

\section{REFERENCES}

Abd El-Fattah, M.A.; F.H.El-gehinbihi and M.A. Sorial.2001. Mitigation of adverse effects of water stress imposed at different growth stages of Taro (Colocasia esculenta L.) plants using several treatments. 1. Physiological response of taro plants to water stress in relation to soil conditioners and slow release fertilizers. Minfiya J. Agric. Res. 26(4):977-1003.

Abd El-Fattah,M.A.; and M.E. Sorial. 2001. Mitigation of the adverse effects of water stress imposed at different growth stages of Taro (Colocasia esculenta L.) Schott plants using several treatments. III. Effects of Mulching and $\mathrm{K}$ Fertilizer Application and their Interaction. Minufiya J. Agric. Res., 26(4):1035-1-69.

Bao-Zhang Yuan; N.Soichi and Y.Kang.2003. Effect of Different Irrigation Regimes on the Growth and Yield of Drip Irrigated Potato. Agric. Water Management (36):153-167, Beijing 100101, PR China.
Doorenbos, J. and W.O. Pruitt. 1984. Crop Water Requirements. Irrigation and Drainage Paper No. 24,FAO, Rome, Italy.

Ismail, S.M.2002. Design and Management of Field Irrigation Systems. (In Arabic), $1^{\text {st }}$ Ed, Monshaet El-Maaref. Puplication, Alexandria, Egypt.

James, L.G. 1988. Principles of Farm Irrigation Systems Design. John Wiley and Sons. Inc. New Yourk, USA.

Jensen, M.E. 1983. Design and Operation of Farm Irrigation Systems. Amer. Soc. Agric. Eng. Michigan, USA. P.827.

Kashyap, P.S. and R.K. Panda. 2002. Effect of Irrigation Schedule on Potato Crop Parameters under Water Stressed Conditions. Agric. Water Management (59):4966. Kharagpw 721302, West Bengal., India.

Nair, G.M. and V.M. Nair. 195. Influence of irrigation and fertilizers on the growth attributes of sweet potato. J. Root crop, 21(1):7-23.

Okeefe, D.M. and D.M. Sylvia. 1992 Chronology and mechanism of $\mathrm{P}$ uptake by mycorrhizae and sweet potato plants. New phytoloist, Vol. 122, No. 4, pp651-659.

Said, M.S., M.A. El-Beheidi; M.A.I. Khalil, T.M. El-Gazar and O.M. El-Hassan. 1984. Studies on the Effect of Some Cultural Practices on Sweet Potato Yield (Ipomreabatats,L.). I. Effect of Water Supply and Nitrogen Fertilization. J. Agric. Sci. Mansoura Univ., 9(3):422-427.

Salem El-Araby, E.L.R. 2002. Response of Sweet Potato to K and Bio-fertilizers under Various Water Stress Conditions. MSc. Thesis. In Vegetable crops. Fac. Agric. Alexandria univ. Egypt.

Steel, R.G.D. and T.H. Torrie. 1960. Principle and Procedures of Statistics. M.C. Graw Hill, NY, USA.

Vermeirer, L. and G.A. Topling. 1984. Localized Irrigation. FAO. Irrigation and Drainage Paper No. 36. Rome, Italy.

Vladimic, K. and M. Bucher. 2005. Symbiotic Phosphorous Transport in Arbuscular Mycorrhizae. Trends in Plant Science Vol. 10No.1 pp.22-29. 


\section{الملخص العربي}

\section{إستجابة محصول البطاطا لعاملات الميكوريزا ومعاملات الرى تحت الرى بالتنقيط في الأراضى الرملية}

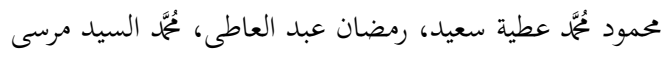

تعادل 80\% من بخر نتح المصول لموسمى النمو الأول والثانى

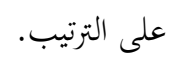

• يوجـد تأثير معنوى لمعاملة إضـافة الميكوريزا والرىى بكميـة ميـاه

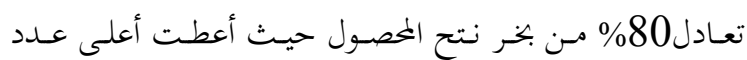

جذور بطاطا/نبات وأعلى وزن جذور وأعلى طول جذا وندر وأعلى قطر وكذلك أعلى نسبة مئوية للمادة الجافة.

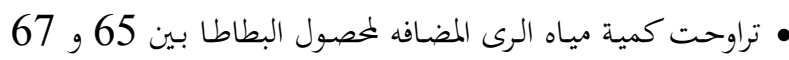

$$
\text { سم لموسمى النمو على الترتبز }
$$

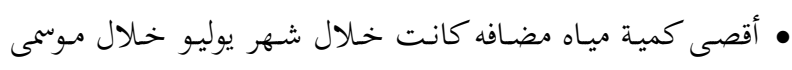

$$
\text { النمو. }
$$

• أعلى كفاءة استعمالية لمياه الرى المضافة كانت لمعاملة الرى أر ومع كع 3.69 .93$.

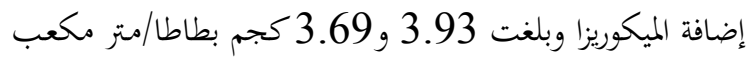

$$
\text { مياه رى مضافة لموسمى النمو على التوالى. }
$$

• التلقيح بالميكوريزا أعطت أعلى محتوى من الفوسفور فن جذأنور

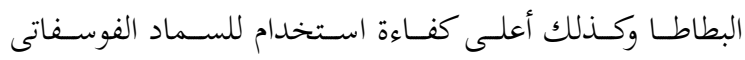

$$
\text { المستخدم على موسمى النمو المتتاليين. }
$$

أجريت تجربتان حقليتان بالمزرعة البحثية بقرية على مبارك بنطقة

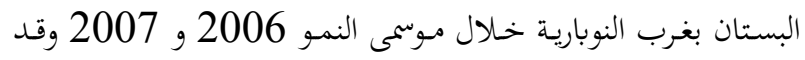
استهدفت الدراسة مدى استجابة نبات البطاطا لمعاملات الميكوريزا

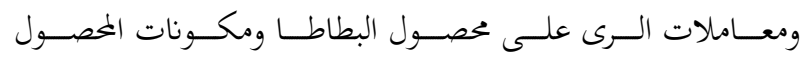

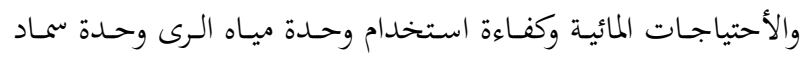
الفوسفور تحت نظام الرى بالتنقيط وكانت معاملات الميكوريزا هى:

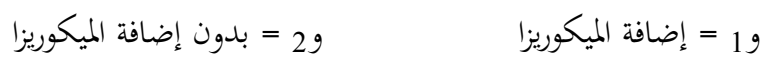

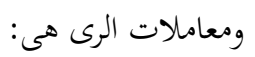

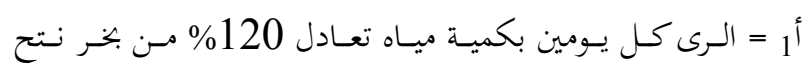

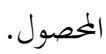
أح = الرى كـل يـومين بكميـة ميـاه تعسادل 100\% مـن بخـر نتح

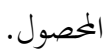
أ3=الرى كل يومين بكمية مياه تعادل 80\% من بخر نتح الخصول. أب = الرى كل يومين بكمية مياه تعادل 60\% من بخر نتح الخصول. وقد أوضحت النتائج المتحصل عليها ما يلى:

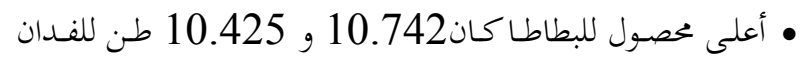
مع معاملة إضافة الميكوريزا عند الزراعة وعند الرى بكمية مياه 